INTERNATIONAL JOURNAL OF PUBLIC DEVOTION

e-ISSN: 2614-6762 dan p-ISSN: 2614-6746

Volume 2 Number 1, July 2019

\title{
Community Empowerment through Freshwater Fish Processing (Toman) as a Result of Processed Creative Communities in Kumba Village, Jagoi Babang District, Bengkayang Regency
}

\author{
Emi Sulistri ${ }^{1}$, Lili Yanti ${ }^{2}$, Sri Mulyani ${ }^{3}$, Nurhayati ${ }^{4}$, Sumarli $^{5}$, Heru Susanto ${ }^{6}$, Rini Setyowati ${ }^{7}$, \\ Rika Wahyuni ${ }^{8}$, Erdi Guna Utama'
}

\section{STKIP Singkawang, Singkawang, Indonesia}

sulistriemi@gmail.com ${ }^{1}$,liliyantiana18@gmail.com²,srimulyani.stkip@gmail.com², nurhayati@stkipsingkawang.ac.id ${ }^{4}$, sumarliphysics@ $@$ gmail.com $^{5}$, ,anto_heru@yahoo.co.id $^{6}$, rini1989setyowati@gmail.com ${ }^{7}$, rikawahyuni142@gmail.com ${ }^{8}$, erdi.guna.utama@gmail.com ${ }^{9}$

\author{
Keywords : \\ Freshwater Fish, Toman \\ Fish, Abon, Kumba \\ Village
}

\begin{abstract}
Training and mentoring are conducted for Kumba hamlet residents, especially among housewives in Jagoi Babang District. This mentoring program involves the lecturers and students of KKN STKIP Singkawang. A method that is used is the identification of the programs is socialization, training, and mentoring directly resulted in the form of the manufacturing practice of toman fish Abon. Toman fish processing into Abon is one way to utilize the potential of toman fish as a skills program to maximize innovative, creative and economic empowered business opportunities. The results of this socialization activity are students can play an active role in the activities and participants involved in Kumba Village can be understood the material presented. Overall, community empowerment partners can understand and practice material related to how they are created, the benefits, and marketing management. However, more intensive assistance is needed for business management related to business planning and financial management.
\end{abstract}

\section{INTRODUCTION}

Toman fish are known as Giant Snakehead because they have a fatter body than cork fish. Toman fish habitat is located in the Sentarum Lake National Park area of Kapuas Hulu district which has expanded to Jagoi Babang district (Murdani, 2016: 2). Toman fish is one of the popular food commodities and consumed by the community aside from being an export commodity. In general, fish quickly decompose when compared with other food ingredients. Bacteria and chemical changes in dead fish cause spoilage. Based on this fact, it is necessary to preserve fish or processed fish technology so that it can extend its shelf life, including innovation in processing fish into shredded fish.

Toman fish are a type of wild fish from the cork fish family (Channidae) (Ebanasar, 1995). Toman fish is the largest species in the Gabus fish tribe. In English, the Toman fish is known as red snakehead, redline snakehead. The term 'snakehead' refers to the shape of its head which resembles the head of a 
snake. Toman fish spread in Sumatra, Kalimantan, Malaysia, Thailand, Laos, Vietnam, Myanmar, and India. The benefits of toman fish are helping the growth and development of a child's bones, improving brain performance, controlling blood pressure, preventing heart disease, reducing the risk of diabetes, reducing the risk of breast cancer, containing proteins that help replace damaged cells, and helping the healing of wounds (Ebanasar, J. and V. Jayaprakas. 1995).

Agricultural and fishery commodities generally have a short shelf life because they are perishable. Efforts to extend shelf life and improve flavor can be done by processing food. With processing, one type of food can be made of various kinds of products with different tastes. One of the processed products is shredded (Fachruddin, 2015). According to Astawan (2015), the process of making shredded has not been standardized, because of the many ways and spices used, this causes the quality of shredded varies, especially in terms of taste and color. The principle of making Abon is boiling meat, fiber, mixing seasonings, brown sugar, salt, and frying oil until dry.

The effort to develop the shredded industrial is not so difficult because the raw materials for making shredded are easily obtained in every region. The selection of raw materials can be based on the availability of the types of raw materials contained in the area and the ease of obtaining them (Fachrudin, 2015). Shredded is one of the processed products that are well known to many people. In general, shredded meat is processed from beef and chicken. Abon making is one alternative to fish processing. This is done to anticipate the abundance of production or to diversify fishery products.

Toman fish processing into "Abon" is one way to exploit the potential of Toman fish as a skills program to maximize innovative, creative and economic empowered business opportunities. Shredded fish is also beneficial for health. This method is an attempt to process Toman fish into shredded to anticipate the abundance of production or diversification of fishery products. By drying raw materials that have been added spices to increase flavor and extend shelf life.

Kumba Village is one of the villages located in the border area between Indonesia and Malaysia. Kumba Village is located in Jagoi Babang District, Bengkayang Regency, West Kalimantan. Kumba Village is one of the villages that have Toman fish income potential. Community life in the village of Kumba or more precisely in the hamlet of Saparan during the transition from the dry season to the rainy season. That's when a lot of Toman fish produced there. As a result of this season's transition, toman fish are easier to catch, because river water will overflow, so fish will come out of their nests. In addition, during the dry season fish are also more easily caught by fishing because fish gather at one hole or place. Meanwhile, during the rainy season, toman fishes are caught using traps made from bamboo. The fishing done by the Kumba village community is still environmentally friendly, using fishing rods and traps earlier so that the preservation of nature and the population of toman fish is maintained.

The purpose of this activity is to provide community empowerment through the processing of freshwater fish (toman) as a result of the processed creative community in Kumba Village, Jagoi Babang District, Bengkayang Regency. The main target of this activity is the community, especially housewives. The target is more precisely aimed at mothers, because there are still many mothers there who do not have work or just take care of the household. So that this empowerment is expected to create new jobs, especially for women and mothers there. As well as getting new innovations in Toman fish processing, in addition to the development of processing that has been obtained can develop insight and economic results of the local community.

Toman fish processing development is expected to increase insight for the community so that the community is more creative and innovative in processing toman fish. So that the processed fish from toman can not only be enjoyed by the local community, but also can be known by the outside community as a typical preparation from the village of Kumba. This certainly can improve the economy of the people there. With this activity, the community is expected to be able to create new jobs to improve the economy there. 


\section{METHOD}

Training and mentoring can train the skill of toman fish Abon processing. Training and mentoring are conducted for Kumba hamlet residents, especially among housewives in Jagoi Babang District. This mentoring program involves the lecturers and students of KKN STKIP Singkawang. A method that is used is the identification of the programs is socialization, training, and mentoring directly resulted in the form of the manufacturing practice of toman fish Abon.

Socialization is undertaken by inviting the housewives to discuss the creative efforts that we can do to increase the variety for processed food and the family income, by utilizing the results of the local fish are Toman in the village of Kumba of Jagoi Babang district. Training is given directly to housewives as the manufacture targets of Abon to prepare all tools and materials in training. The training is given for 2 months at the end of every week by lecturers and KKN students of STKIP Singkawang. While for mentoring made for 1 month until the process of packing Abon of fish that they will be marketed.

In this activity equipment design was not carried out because the service was in the form of socialization. The method of the data collection and analysis data was undertaken by trying directly the results processed of Abon to know the level of the success of this community empowerment.

\section{RESULTS AND DISCUSSION}

\section{ORIENTATION AND SOCIALIZATION}

The community empowerment program in the form of diversification of toman fish in Abon form will begin with orientation and outreach activities. At the time of this orientation at the same time carried out for licensing reporting activities to the Head of Kumba Village. The target of community empowerment activities is aimed at the entire community, especially housewives who live in Saparan Hamlet, Kumba Village. Before the socialization activity, observations were carried out to determine the level of knowledge possessed by the participants about the benefits of fish, its nutritional content, as well as how to process them into high nutritional value food products. Then, in the information dissemination activities, some information was presented including the objectives of the activity and the schedule of training activities.

On the occasion of the socialization also distributed leaflets and delivered the socialization of profits and benefits of the production of Abon of fishes toman. The advantage gained from the processing of toman fish into Abon fish is to increase the selling value of the processed products. Improving the economy of the local community and also empowering women and housewives to create new jobs. While the benefits that can be obtained are toman fish will be more durable and long-lasting if processed in a dry form such as Abon, abundant toman fish can be utilized by residents to process it into superior products from the village.

The results of this socialization activity are students can play an active role in the activities and participants involved in Kumba Village can be understood the material presented. The method used is a question and answer as shown in Figures 1 and 2. 


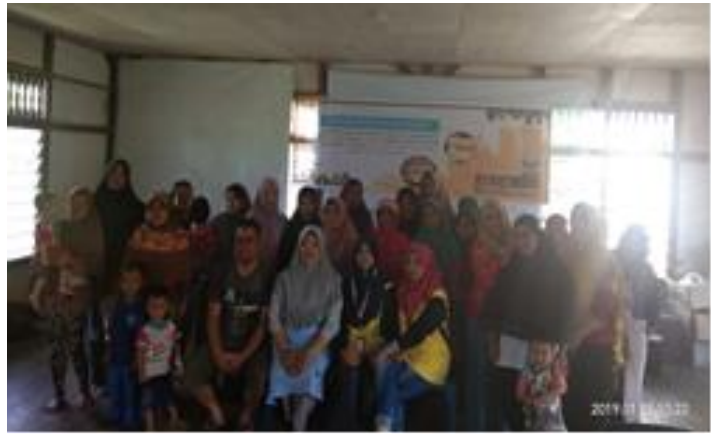

Fig 1. Participants in thesocialization of Community Empowerment activities in Kumba Village

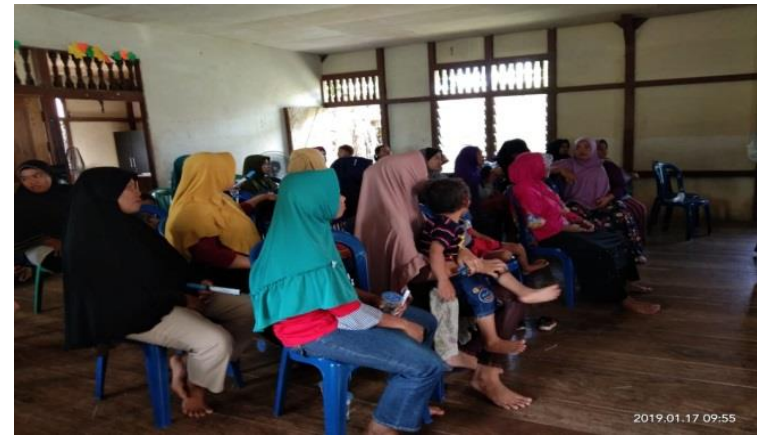

Fig 2. Housewives listening to socialization

\section{TRAINING AND MENTORING RESULT}

This activity was carried out jointly between the training participants and the community service team (lecturers and KKN students) as shown in figures 3 and 4 . The time allocation required for this program was greater than for the socialization program which was for 2 months. This is intended so that the participants can really practice how to process fish into shredded fish as shown in Figure 5.

The results of the training show that there are still some mothers who cannot process shredded properly. Like when drying shredded oil, this can be overcome by providing assistance from a dedicated team and assisted by other participants who can make abun well. In addition to providing assistance in the process of making shredded fish, the service team also provided assistance to packaging shredded toman fish to be marketed. During the 1-month mentoring, participants understood that in addition to the ability to make the right shredded, the participants also understood how a good packaging looked when packing the shredded processed product.

Evaluation is carried out on the work of the training participants and mentoring both individually and in groups. Based on the results of the evaluation team of dedication, it can be seen that the participants of the training are able to practice ways of preparing fish raw material for the manufacture of the shredded product and understand the steps of processing work.

The process of making shredded meat takes a long time because it takes a long time to process fish into shredded fish. Activities carried out during the rainy season where it will be difficult to get toman fish, so the fish are replaced with cork fish that are similar to the texture of toman fish. However, the texture and taste of shredded itself do not change.

Overall, community empowerment partners can understand and practice material related to how they are created, the benefits, and marketing management. However, more intensive assistance is needed for business management related to business planning and financial management.

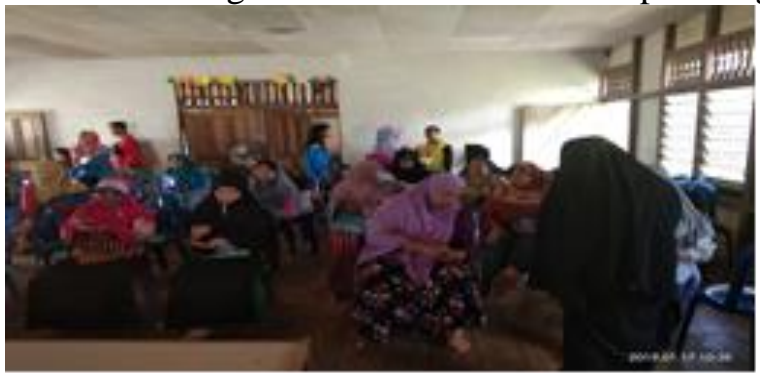

Fig 3. Evaluation of training results

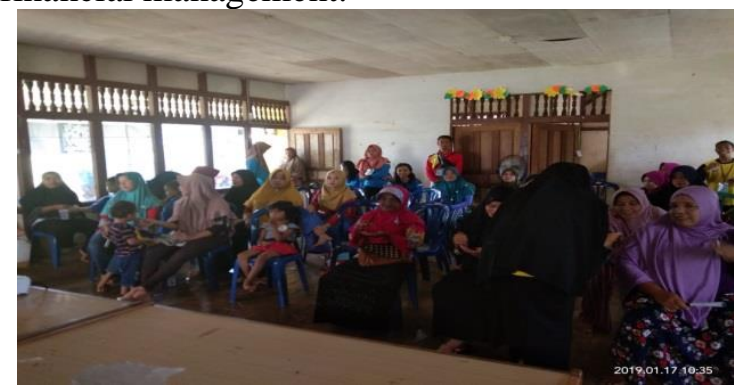

Fig 4. One participant describing the results of the practice 


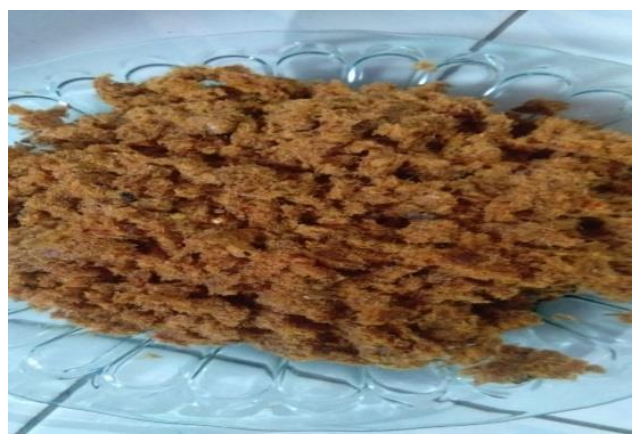

Fig 5. Toman Fish Processed into Abon Form

\section{IMPACT OF COMMUNITY SERVICE ACTIVITIES AND IMPLEMENTATION DIFFICULTIES}

Based on observations at the community empowerment business location, the impact of the implementation of counseling and training on Abon processing from toman fish has shown a positive impact. The people in Kumba Village began to pay more attention to the Abon products from toman fish and have a desire to make a business and market it. So far, they only know Abon of beef which is widely sold in the market. For this reason, efforts should be made to introduce products to the community through exhibitions or counseling on major holidays.

The difficulty in carrying out these community empowerment activities lies in the busyness of the community members who work so that only a few attend the socialization. In addition, the process of making floss which is counted long makes the participants impatient to wait for the results. Then the difficulty of Abon raw material processing in which toman fish must be replaced with cork fish because toman fish can only be obtained during the dry season, then these difficulties can be immediately overcome in the extension and training. 


\section{CONCLUSION AND SUGGESTION}

\section{CONCLUSION}

Some conclusions that can be drawn from these community empowerment activities are:

1. This community empowerment activity received a positive response from the people of Kumba Village as evidenced by the active involvement of the community and improvement of community skills in the implementation of the diversification of processed freshwater fish.

2. This community empowerment partner can practice shredded product processing well even though it is still in the training stage.

3. People in Kumba Village get a new insight that freshwater fish such as toman fish can be used as processed shredded that is nutritious and has high economic value.

\section{SUGGESTIONS}

Suggestions for the next community service activities are products that will be processed able to break through the market with high sale value that can be a capital for community and regional development.

\section{ACKNOWLEDGMENTS}

We would like to acknowledge for STKIP Singkawangand the Head of Community Service Institutions who have given our group the opportunity to carry out one of our obligations from the "Tri Darma Perguruan Tinggi" which is community service. Thanks also go to the Head of Kumba Village and Kumba Village residents who have agreed to participate in this activity.

\section{REFERENCES}

Ismail \& Putra. 2017. Inovasi Pembuatan Abon IkanCakalang dengan Penambahan Jantung Pisang.Politeknik Negeri Jember: Jember. 1.https://www.neliti.com/publications/217400/inovasi-pembuatan-abon-ikancakalangdenganpenambahan-jantung-pisang.Access on January 27th, 2019.

Kusumayanti, dkk. 2011. Inovasi Pembuatan Abon Ikan sebagai Salah Satu Teknologi Pengawetan Ikan. Fakultas Teknik Universitas Negeri Semarang: Semarang. Vol. 16 No. 3. Access on January 27th, 2019.

Murdani, Oka Jaya. 2016. Uji Efek Penyembuhan Luka Sayat Ekstrak Ikan Toman (Channa Micropeltes) secara Oral pada Tikus Jantan Galurwistar yang di Induksi Streptozotocin. F. Kedokteran, Universitas Tanjungpura: Pontianak. Access on January 27th, 2019.

Naveh, HR, dkk. 2016. Both Omega-3 and Omega-6 Polyunsaturated Fatty Acids Stimulate Foot Wound Healing in Chronic Diabetic Rat. Afr J of Pharm and Pharmacol. 2011. Access on January 29th, 2019.

Omar MN, dkk. 2016. ஸ́- Fatty Acids from Malaysian Giant Snakehead (Channa Micropeltes) Fish Oil. Ori J of Chem. 2010. Access on January 29th, 2019.

Prayitno, M. 2012. Inovasi Produk Baru Abon. https://respository.unika.ac.id/10118/. Access on January 26th, 2019.

Sukesi dan Millah. 2009. Produksi Abon Ikan Pari (Rayfish): Penentuan Kualitas Gizi Abon. Institut Teknologi Sepuluh Nopember: Surabaya. https://digilib.its.ac.id. Access on January 26th, 2019.

Suryani, A, ErlizaHambali, dan Encep Hidayat. 2017. Membuat Aneka Abon. Penebar Swadaya: Jakarta.https://ejournal.undip.ac.id.Access on January $26^{\text {th }}, 2019$. 